\title{
OPTIMASI KANDUNGAN GIZI SUSU KAMBING PERANAKAN ETAWA (PE) MENGGUNAKAN ELM-PSO DI UPT PEMBIBITAN TERNAK DAN HIJAUAN MAKANAN TERNAK SINGOSARI-MALANG
}

\author{
Imam Cholissodin', Sutrisno², Arief Andy Soebroto ${ }^{3}$, Latifah Hanum ${ }^{4}$, Canny Amerilyse Caesar ${ }^{5}$ \\ 1,2,3,4,5Fakultas Ilmu Komputer Universitas Brawijaya \\ Email: 1imamcs@ub.ac.id, ${ }^{2}$ trisno@ub.ac.id, ${ }^{3}$ ariefas@ub.ac.id, ${ }^{4}$ hanum_latifah@ymail.com, \\ ${ }^{5}$ camerilyse@outlook.com
}

(Naskah masuk: 30 Desember 2016, diterima untuk diterbitkan: 14 Februari 2017)

\begin{abstract}
Abstrak
Susu merupakan salah satu sumber protein hewani yang mengandung semua zat yang dibutuhkan tubuh. Ternak penghasil susu utama di Indonesia yaitu sapi perah, namun produksi susunya belum dapat mencukupi kebutuhan masyarakat. Alternatifnya adalah kambing peranakan etawa (PE). Tingginya kualitas kandungan gizi susu sangat dipengaruhi oleh beberapa faktor salah satunya, yaitu faktor pakan. Bagian peternakan kambing PE di UPT Pembibitan Ternak dan Hijauan Makanan Ternak Singosari-Malang masih menghadapi permasalahan, yaitu rendahnya kemampuan dalam memberikan komposisi pakan terhadap kambing PE. Kekurangan tersebut berpengaruh terhadap kualitas susu yang dihasilkan. Diperlukan pengetahuan rekayasa kandungan gizi susu untuk menentukan komposisi pakan dalam menghasilkan susu premium dengan kandungan gizi optimal. Penulis menggunakan metode Extreme Learning Machine (ELM) dan Particle Swarm Optimization (PSO) untuk membuat pemodelan pakan kambing dalam mengoptimasi kandungan gizi susu kambing. Dalam analisa pengujian konvergensi menggunakan metode ELM-PSO yang dilakukan dengan kasus untuk berat badan kambing $32 \mathrm{~kg}$, serta jenis pakan yang digunakan yaitu rumput Odot $70 \%$ dan rumput Raja 30\% menghasilkan sistem mencapai kestabilan dalam konvergensi pada iterasi ke-20 dengan fitness terbaik yaitu 16.2712.
\end{abstract}

Kata Kunci: Susu Kambing, Optimasi, Artificial Neural Network (ANN), Particle Swarm Optimization (PSO), Genetic Algorithm (GA), Kandungan Nutrisi Pakan.

\begin{abstract}
Milk is one of the animal protein sources which it contains all of the substances needed by human body. The main milk producer cattle in Indonesia is dairy cow, however its milk production has not fulfilled the society needs. The alternative is the goat, the Etawa crossbreed (PE). The high quality of milk nutrients content is greatly influenced by some factors one of them, is the food factor. The PE goat livestock division of the UPT Cattle Breeding and the Cattle Food Greenery in Singosari-Malang still faces the problem, it is the low ability in giving the food composition for PE goat. This flaw affects the quality of the produced milk. It needs the artificial science of the milk nutrients contains in order to determine the food composition to produce premium milk with the optimum nutrients contain. The writer uses the method of the Extreme Learning Machine (ELM) and the Particle Swarm Optimization (PSO) to make the modeling of goat food in optimizing the content of goat milk nutrients. In the analysis of the convergence that is done with the case of $32 \mathrm{~kg}$ goat weight, also the food type used is the $70 \%$ Odot grass and 30\% Raja grass that system get a stability on the $20^{\text {th }}$ iteration with a fitness value is 16.2712.
\end{abstract}

Keywords: Goat Milk, Optimization, Extreme Learning Machine (ELM), Particle Swarm Optimization (PSO), The Food Nutrients Contain.

\section{PENDAHULUAN}

Susu merupakan bahan makanan istimewa yang mengandung semua zat yang dibutuhkan tubuh yang mudah dicerna dan dimanfaatkan oleh tubuh. Susu merupakan jenis bahan pangan hewani berupa cairan putih yang dihasilkan oleh ternak mamalia seperti sapi, kerbau atapun kambing dan diperoleh dengan cara pemerahan (Hamidah, Sukada, \& Swacita, 2012). Menurut Kepala Badan Kependudukan dan Keluarga Berencana Nasional (BKKBN) Surya Chandra Surapaty menjelaskan bahwa laju pertumbuhan penduduk Indonesia saat ini mencapai $1,49 \%$ tiap tahun dari jumlah penduduk Indonesia (Akuntono, 2015). Seiring dengan bertambahnya populasi penduduk dan pendapatan serta kesadaran masyarakat akan gizi mengakibatkan kebutuhan protein hewani menjadi meningkat sehingga perlu dilakukan pemenuhan kebutuhan protein hewani dengan cara meningkatkan salah satu produksi ternak, yaitu susu (Nur, Setyowati, \& Wahyuningsih, 2015).

Ternak penghasil susu utama di Indonesia adalah sapi perah Peranakan Friesian Holstein (PFH) yang produksi susunya relatif masih rendah. 
Rendahnya produksi susu sapi perah jenis PFH tidak dapat mencukupi kebutuhan protein hewani yang dibutuhkan oleh masyarakat. Ternak perah alternatif yang cocok untuk dikembangkan dan dapat diterima oleh masyarakat adalah kambing peranakan etawa (PE) (Nur, Setyowati, \& Wahyuningsih, 2015). Kambing PE adalah salah satu penyedia protein hewani asal ternak berupa daging atau susu. Salah satu kelebihan susu kambing adalah kandungan gizinya relatif lebih lengkap dan seimbang (Fitriyanto, Astuti, \& Utami, 2013).

Bagian peternakan kambing peranakan etawa (PE) di UPT Pembibitan Ternak dan Hijauan Makanan Ternak Singosari-Malang masih menghadapi permasalahan, yaitu rendahnya kemampuan dalam memberikan treatment komposisi pakan terhadap kambing peranakan etawa. Kekurangan tersebut selain mengakibatkan lambatnya pertumbuhan produksi susu juga berpengaruh terhadap kualitas susu yang dihasilkan (Nugroho, 2010).

Permasalahan rekayasa kandungan gizi susu kambing agar dapat optimal tersebut dapat diselesaikan dengan beberapa metode pemodelan. Pada penelitian yang sebelumnya, permasalahan rekayasa kandungan gizi susu kambing dapat dioptimalkan dengan menggunakan metode pemodelan Artificial Neural Network (ANN) dan Genetic Algorithm (GA) serta Artificial Neural Network (ANN) dan Particle Swarm Optimization (PSO). Berdasarkan penelitian sebelumnya yang menggunakan metode ANN-GA, didapatkan bahwa kandungan protein dengan kualitas susu premium untuk berat badan $36 \mathrm{~kg}$ adalah mengalami kenaikan protein sebesar $0.707 \%$ dan penurunan lemak sebesar $0.879 \%$ setelah dilakukan proses optimasi (Amerilyse, Hanum \& Cholissodin, 2016). Sedangkan, berdasarkan penelitian sebelumnya yang menggunakan metode ANN-PSO, didapatkan bahwa kenaikan kandungan protein dengan kualitas susu premium untuk berat badan $36 \mathrm{~kg}$ adalah $0.0852 \%$ dan penurunan kandungan lemak sebesar $2.23254 \%$ setelah dioptimasi (Amerilyse, Hanum \& Cholissodin, 2016).

Pada penelitian sebelumnya yang dilakukan oleh Karpagachelvi S. (2014) tentang pengklasifikasian sinyal ECG dengan menggunakan hybrid algorithm,yaitu ELM dan PSO. EKG adalah hasil rekaman jantung yang digunakan untuk menyelidiki penyakit jantung. EKG dapat diklasifikasikan sebagai sinyal normal dan abnormal. Penerapan ELM dan PSO pada pengklasifikasian sinyal ECG bertujuan untuk mengoptimalkan pemilihan fitur dan parameter dari ELM. Hasil dari penelitian ini menjelaskan bahwa pengklasifikasian sinyal ECG dengan menggunakan pendekatan hybrid algorithm ELM dan PSO lebih unggul dan akurat jika dibandingkan dengan pengklasifikasian sinyal ECG secara tradisional (S, 2014). Berdasarkan beberapa penelitian yang sebelumnya, permasalahan rekayasa kandungan gizi susu kambing PE diselesaikan dengan menggunakan metode Extreme Learning Machine (ELM) dan Particle Swarm Optimization (PSO) sebagai metode otpimasinya.

Pada penelitian ini diusulkan teknik optimasi kandungan gizi susu kambing PE di UPT Pembibitan Ternak dan Hijauan Makanan Ternak SingosariMalang menggunakan kombinasi Extreme Learning Machine (ELM) dan Particle Swarm Optimization (PSO) berdasarkan pada paper sebelumnya oleh Karpagachelvi S. Alasan utama menggunakan penggabungan kedua metode tersebut agar hasil yang didapatkan dari sistem kami dapat mencapai hasil yang optimal dengan pembelajaran yang cepat.

\section{DASAR TEORI}

\subsection{Extreme Learning Machine (ELM)}

ELM ini pertama kali diperkenalkan oleh Huang (2004), dan ELM merupakan jaringan syaraf tiruan (JST) feedforward dengan single hidden layer atau disebut dengan Single Hidden Layer Feedforward Neural Networks (SLFNs) (Sun, Choi, Au, \& Yu, 2008). Pada Gambar 1 dan Gambar 2, Metode pembelajaran ELM dibuat untuk mengatasi beberapa kelemahan dari JST feedforward, terutama dalam hal learning speed. Berikut model matematis dari ELM pada data $\left(\mathrm{x}_{\mathrm{i}}, y_{i}\right)$ (Huang, Zhu, \& Siew, 2005).

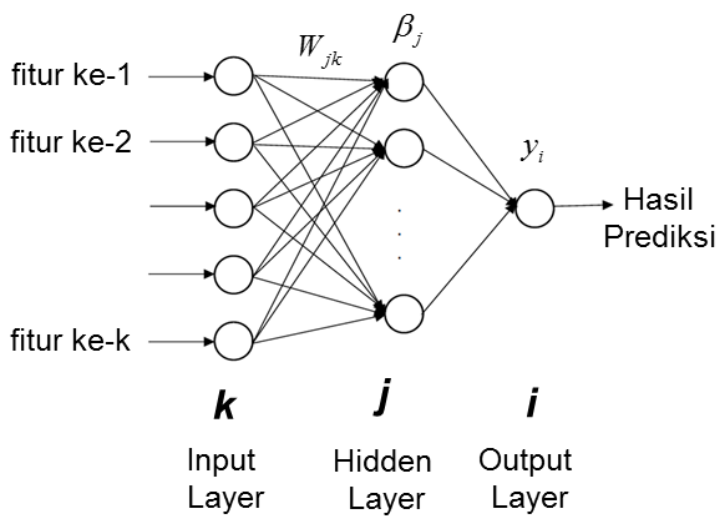

Gambar 1. Arsitektur ELM

Langkah-langkah training algoritma ELM tanpa bias (Cholissodin, 2016):

1. Buat random $W_{j k}$ sebagai bobot masukan.

2. Hitung matrik keluaran hidden layer $H=$ $1 /\left(1+\exp \left(-X . W^{T}\right)\right)$

3. Hitung output weight $\hat{\beta}=H^{+} . Y \quad$ dimana $\mathrm{H}^{+}=\left(\mathrm{H}^{\mathrm{T}} \cdot \mathrm{H}\right)^{-1} \cdot \mathrm{H}^{\mathrm{T}}$

4. Hitung $\hat{Y}=H \cdot \hat{\beta}$

Langkah-langkah testing algoritma ELM tanpa bias:

1. Diketahui $W_{j k}$, dan $\hat{\beta}$

2. Hitung $H=1 /\left(1+\exp \left(-X_{\text {test }} \cdot W^{T}\right)\right)$

3. Hitung $\hat{Y}=H \cdot \hat{\beta}$

4. Hitung nilai evaluasi, misal dengan MAPE, MAE, MSE atau lainnya. 


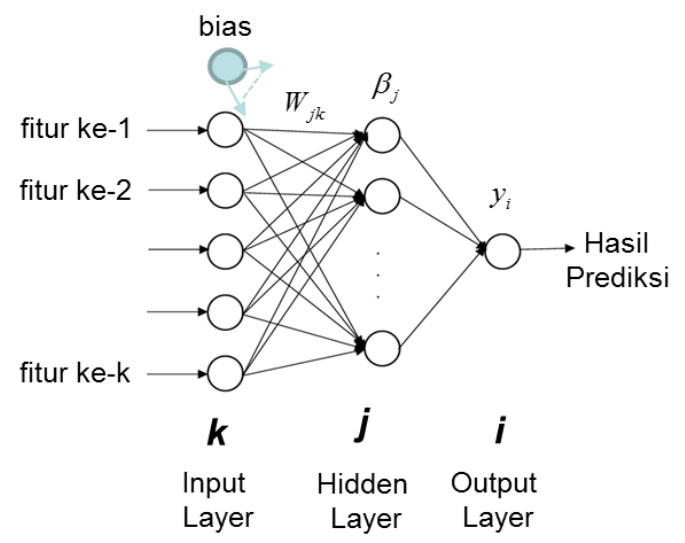

Gambar 2. Arsitektur ELM dengan bias

Langkah-langkah training algoritma ELM dengan bias:

1. Buat random $W_{j k}$ sebagai bobot masukan dan nilai bias $b$ jika ada. Ukuran matrik bias $b$ adalah $[1 \times j]$

2. Hitung matrik keluaran hidden layer $H=$ $1 /\left(1+\exp \left(-\left(X . W^{T}+\right.\right.\right.$ ones $\left.\left.\left.\left(N_{\text {train }}, 1\right) * b\right)\right)\right)$. Dan $N_{\text {train }}$ adalah banyaknya data training.

3. Hitung output weight $\hat{\beta}=H^{+} . Y \quad$ dimana $\mathrm{H}^{+}=\left(\mathrm{H}^{\mathrm{T}} \cdot \mathrm{H}\right)^{-1} \cdot \mathrm{H}^{\mathrm{T}}$

4. Hitung $\hat{Y}=H \cdot \hat{\beta}$

Langkah-langkah testing algoritma ELM dengan bias:

1. Diketahui $W_{j k}$, nilai bias $b$ jika ada, dan $\hat{\beta}$

2. Hitung $H=1 /\left(1+\exp \left(-\left(X_{\text {test. }} W^{T}+\right.\right.\right.$ ones $\left.\left.\left.\left(N_{\text {test }}, 1\right) * b\right)\right)\right)$

3. Hitung $\hat{Y}=H . \hat{\beta}$

4. Hitung nilai evaluasi, misal dengan MAPE, MAE, MSE atau lainnya.

Di mana batas bawah dan batas atas nilai $W_{j k}$ ada yang menggunakan $[-1 ; 1],[-0.5 ; 0.5]$ atau nilai batas lainnya yang bisa digunakan untuk skenario pengujian, begitu juga dengan $b$.

\subsection{Algoritma Particle Swarm Optimization (PSO)}

PSO merupakan sebuah algoritma pencarian berbasis populasi berdasarkan simulasi perilaku sosial burung dalam sebuah swarm. Perilaku sosial ini terdiri dari tindakan individu dan pengaruh dari individu-individu lain dalam suatu kelompok. Setiap individu berperilaku secara terdistribusi dengan menggunakan kecerdasannya (intelligence) sendiri dan juga dipengaruhi kelompok kolektifnya. Berikut langkah-langkah dalam algoritma PSO:

\section{Inisialisasi Partikel}

Diasumsikan bahwa sebuah partikel untuk setiap dimensinya harus berada dalam domain yang didefinisikan oleh dua vektor, $\mathrm{x}_{\min }$ dan $\mathrm{x}_{\max }$ yang mewakili batas bawah dan batas atas setiap dimensi yang ditunjukkan pada Persamaan (1) berikut (Engelbrecht, 2007).

$$
\begin{aligned}
\mathrm{x}_{\mathrm{i}}(0) & =x_{\min , d}+r_{d}\left(x_{\max , d}-x_{\min , d}\right), \forall d \\
& =1, \ldots, n_{x}, \forall_{i}=1, \ldots, n_{s}
\end{aligned}
$$

$X_{i d}$ adalah posisi partikel ke- $i$ pada dimensi ke-d, dimana $r_{j} \sim U(0,1)$ merupakan nilai acak (random) dengan range $[0,1]$. Inisialisasi posisi dari setiap partikel $\left(\mathrm{X}_{\mathrm{id}}\right)$ dan kecepatan dari setiap partikel $\left(\mathrm{V}_{\mathrm{id}}\right)$.

Kecepatan awal dapat diinisialisasi menjadi nol. Ditunjukkan pada Persamaan (2).

$$
V_{\text {id }}(0)=0
$$

$\mathrm{V}_{\text {id }}$ merupakan kecepatan partikel ke- $i$ pada dimensi ke-d, posisi terbaik individu ke- $i$ $\left(p\right.$ Best $\left._{i}\right)$ awal untuk setiap partikel diinisialisasikan dengan posisi partikel pada $t=$ 0 yang ditunjukkan pada Persamaan (3).

$$
\text { pBest }_{i}(0)=x_{i}(0)
$$

\section{Fungsi Objektif PSO}

Untuk mendapatkan nilai fitness, suatu partikel harus dievaluasi berdasarkan suatu fungsi objektif tertentu. Jika permasalahannya adalah optimasi, maka untuk memaksimalkan fungsi $h$, digunakan fungsi objektif $f=h$. Akan tetapi, jika permasalahannya adalah optimasi untuk meminimalkan fungsi $h$, maka digunakan fungsi objektif $f=1 / h$. Rumus fitness untuk mengoptimalkan dan meminimalkan ditunjukkan pada Persamaan (4).

$$
\text { fitness }=x_{-} \text {optimal }+\frac{1}{x_{-} \min }
$$

Keterangan:

x_optimal $=$ nilai yang ingin dioptimalkan

x_min $=$ nilai yang ingin diminimalkan

\section{Personal Best PSO}

Personal Best PSO dalam kasus maksimal optimasi secara umum didapatkan dengan membandingan nilai fitness saat ini dengan nilai $p B e s t$ sebelumnya, jika fitness saat ini $>$ dari fitness sebelumnya, maka pBest $=$ posisi saat ini, seperti yang ditunjukkan pada Persamaan (5).

$$
\left\{\begin{array}{l}
\text { pBest }_{i}(t) \text { jika } f\left(x_{i d}(t+1)\right) \geq f\left(\text { pBest }_{i}(t)\right) \\
x_{i d}(t+1) \text { jika } f\left(x_{i d}(t+1)\right)<f\left(\text { pBest }_{i}(t)\right)
\end{array}\right.
$$

Keterangan:

$$
\begin{aligned}
& \text { pBest }_{i}(t+1)=\text { pBest iterasi sekarang } \\
& \text { pBest }_{i}(t)=\text { pBest iterasi sebelumnya } \\
& f\left(x_{i d}(t+1)\right)=\text { nilai fitness iterasi sekarang }
\end{aligned}
$$




\section{Global Best PSO}

Pencarian nilai gBest pada kasus secara umum dengan cara mencari argumen dari nilai maksimal semua pBest dalam iterasi $t$ yang ditunjukkan pada persamaan (6) berikut:

Keterangan:

$$
k=\arg \operatorname{Max}_{i=1}^{n}\left\{f\left(\operatorname{pBest}_{i}(t)\right)\right\}
$$

$$
\begin{aligned}
& \operatorname{gBest}(t)=\operatorname{pBest}_{k}(t) \\
& \operatorname{argMax}_{i=1}^{n}=\operatorname{argumen} \text { maksimal } \\
& f\left(\operatorname{pBest}_{i}(t)\right)=\text { nilai fitness } \text { pBest }_{i} \text { iterasi }(t)
\end{aligned}
$$

\section{Update Kecepatan dan Posisi}

Kecepatan $\left(V_{i}\right)$ dan posisi dari partikel $\left(X_{i}\right)$ diubah menggunakan persamaan (7).

$$
V_{i d}^{t+1}=w^{*} v_{i d}^{t}+c_{1} * \operatorname{Rand}() *\left(p_{i d}-x_{i d}^{t}\right)+c_{2} * \operatorname{Rand}() *\left(p_{g d}-x_{i d}^{t}\right)
$$

Dengan membandingkan antara kecepatan dan $\mathrm{V}_{\max }$.

$$
v_{\max }=k *\left(x_{\max }-x_{\min }\right)
$$

Rumus perubahan posisi $\left(\mathrm{X}_{\mathrm{i}}\right)$ :

$$
x_{i d}^{t+1}=x_{i d}^{t+1}+V_{i d}^{t+1}
$$

Rumus W inersia (w):

$$
w(i)=w_{\max }-\left(\frac{w_{\max }-w_{\min }}{i_{\max }}\right) \times i
$$

Dimana $w_{\max }$ dan $w_{\min }$ masingmasing adalah nilai awal dan nilai akhir bobot inersia yang nilainya secara berurutan adalah 0,9 dan 0,4 . Sedangkan $i_{\max }$ adalah jumlah iterasi maksimum yang digunakan.

Keterangan:

$$
\begin{gathered}
\begin{aligned}
v_{i d}^{t}= & \text { kecepatan partikel ke- } i \text { pada dimensi } \\
& \text { ke- } d \text { pada iterasi ke- } t
\end{aligned} \\
\begin{aligned}
x_{i d}^{t}= & \text { posisi partikel ke- } i \text { pada dimensi ke- } d \\
& \text { pada iterasi ke- } t
\end{aligned} \\
\begin{aligned}
w= & \text { bobot inersia } \\
c_{1}, c_{2}= & \text { komponen kognitif dan sosial } \\
p_{i d}= & p B e s t \text { atau posisi terbaik partikel pada } \\
& x_{\text {id }}^{t}
\end{aligned} \\
p_{g d}= \\
\text { gBest atau posisi terbaik partikel } \\
\text { secara keseluruhan }
\end{gathered}
$$

\section{Kondisi berhenti}

Jika telah mencapai kondisi akhir (mencapai nilai iterasi maksimum atau perulangan telah mencapai nilai konvergen) maka perulangan berhenti dan nilai optimumnya didapatkan namun jika belum maka kembali melakukan perulangan.

\section{PEMBAHASAN}

Metode yang diusulkan dalam penelitian ini, pada Gambar 3, yaitu menggabungkan ELM-PSO dalam sistem. Sistem kerjanya dibagi menjadi 2 bagian langkah, langkah yang pertama hanya menjalankan metode ELM untuk mendapatkan $W_{j k}$ sebagai bobot masukan yang optimal, atau hanya menggunakan training algoritma ELM tanpa bias. Kemudian langkah yang ke-2 adalah mengoptimasi parameter pakan dengan PSO menggunakan proses testing ELM. Berikut adalah detail langkahnya:

\begin{tabular}{|c|c|c|c|c|c|c|c|c|c|}
\hline N & \multirow{2}{*}{$\begin{array}{c}\text { Nama } \\
\text { Perlakuan }\end{array}$} & \multicolumn{4}{|c|}{ Kandungan Nutrisi } & \multicolumn{4}{|c|}{ Output } \\
\hline No & & Abu & PK & LK & sK & Protein & Lemak & Laktosa & Density \\
\hline 1 & Premium & 0.744 & 0.54 & 0.14 & 0.9936 & 0.514706 & 0.501193 & 0.515152 & 0.573003 \\
\hline 2 & Premium & 0.6324 & 0.459 & 0.119 & 0.84456 & 1 & 1 & 1 & 0.85124 \\
\hline 3 & Premium & 0.651 & 0.4725 & 0.1225 & 0.8694 & 0.544118 & 0.389021 & 0.545455 & 0.724518 \\
\hline 4 & Premium & 0.6696 & 0.486 & 0.126 & 0.89424 & 0.558824 & 0.804296 & 0.560606 & 0.341598 \\
\hline 5 & Premium & 0.7068 & 0.513 & 0.133 & 0.94392 & 0.485294 & 0 & 0.469697 & 1 \\
\hline 6 & Premium & 0.6324 & 0.459 & 0.119 & 0.84456 & 0.441176 & 0.470167 & 0.424242 & 0.46832 \\
\hline 7 & Baik & 0.5952 & 0.432 & 0.112 & 0.79488 & 0.220588 & 0.236277 & 0.227273 & 0.363636 \\
\hline 8 & Baik & 0.6324 & 0.459 & 0.119 & 0.84456 & 0.205882 & 0.236277 & 0.19697 & 0.325069 \\
\hline 9 & Baik & 0.6882 & 0.4995 & 0.1295 & 0.91908 & 0 & 0.238663 & 0 & 0 \\
\hline
\end{tabular}

1. Melakukan proses training data menggunakan algoritma ELM untuk memperoleh nilai input weight $\left(W_{j k}\right)$ dan output weight $(\hat{\beta})$

2. Input weight dan output weight digunakan pada algoritma PSO pada tahapan testing ELM. Pada algoritma PSO akan dilakukan proses inisialisasi partikel dan partikel yang telah terbentuk akan diproses ke dalam testing ELM hingga diperoleh hasil denormalisasinya. Hasil denormalisasi tersebut akan digunakan untuk memperoleh nilai fitness yang dihasilkan oleh setiap partikel. Kemudian, sistem akan mencari nilai personal best (pBest) dan global best (gBest) serta dilakukan proses update kecepatan dan posisi hingga diperoleh satu partikel dengan nilai fitness terbesar sebagai hasil yang diharapkan.

Tabel 1. Kumpulan data berdasarkan perlakuan

Keterangan:

- Abu: zat pakan anorganik yang mengandung unsur-unsur yang dibutuhkan.

- Protein kasar (PK): bahan organik kompleks dengan peranan yang banyak.

- Lemak kasar (LK): kandungan total lipida dalam jumlah yang sebenarnya.

- Serat kasar (SK): sisa-sisa sel tumbuhan yang tahan terhadap reaksi hidrolisis.

Dalam kasus penelitian ini, kandungan nutrisi pakan hijauan berupa Abu, PK, LK dan SK (sebagai $X_{k}$ ) beserta kandungan gizi susunya berupa protein, lemak, laktosa dan density (sebagai $Y_{i}$ ) akan dikomputasi lebih lanjut menggunakan ELM pada langkah ke-1. Pada Tabel 1, dapat digunakan sebagai gambaran untuk merepresentasikan partikel pada PSO. Setiap partikel memiliki dimensi yang merupakan kandungan nutrisi (Abu, PK, LK, dan SK), yaitu $X_{i j}(t)=[$ Abu PK LK SK] atau dapat ditunjukkan pada Persamaan (11).

$$
X_{i j}(t)=\left[\begin{array}{llll}
X_{i 1}(t) & X_{i 2}(t) & X_{i 3}(t) & X_{i 4}(t)
\end{array}\right]
$$


Kemudian untuk rumus fitness-nya menggunakan batasan hanya dua macam variabel output yang akan dikomputasi (bisa dibuat seimbang komposisnya, atau berbanding terbalik, atau dengan menggunakan suatu konstanta pengali sebagai pembobotan) dan output yang lainnya diabaikan, yaitu memaksimalkan kandungan protein dan meminimalkan kandungan lemak, dengan formulasi yang ditunjukkan pada Persamaan (12).

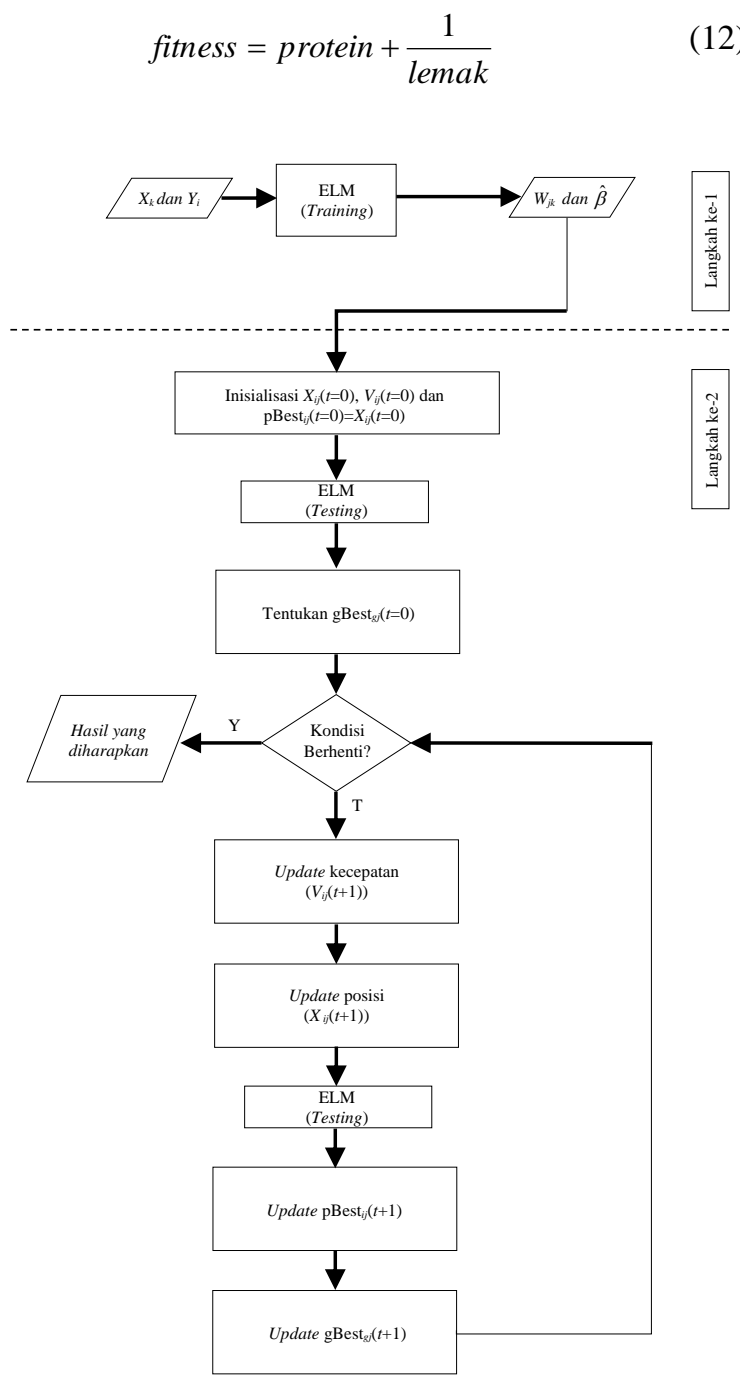

Gambar 3. Algoritma ELM-PSO

\section{PENGUJIAN DAN ANALISIS}

Pengujian konvergensi metode ELM-PSO dengan parameter PSO yang sudah diuji sebelumnya yaitu iterasi maksimal PSO $=100$ iterasi, nilai $w$ Max $=0.6$ dan $w$ Min $=0.3$, nilai $c_{1}=1$ dan $c_{2}=1.5$, nilai $k$ $=0.6$. Dengan parameter ELM yaitu interval yang digunakan adalah $[-0.5,0.5]$, jumlah hidden layer $=4$, jumlah data yang digunakan adalah 5 data. Terdapat 2 jenis pakan yang digunakan dalam pengujian, yaitu Rumput Raja dengan rasio pakan $70 \%$ dan Rumput Odot dengan rasio pakan $30 \%$. Berat badan kambing yang digunakan dibatasi yang hanya $32 \mathrm{~kg}$, tetapi juga bisa dibuat berbeda. Dalam penelitian ini mengoptimalkan kandungan Protein dan meminimalkan kandungan Lemak pada kelas Premium. Grafik pengujian konvergensi ditunjukkan pada Gambar 4.

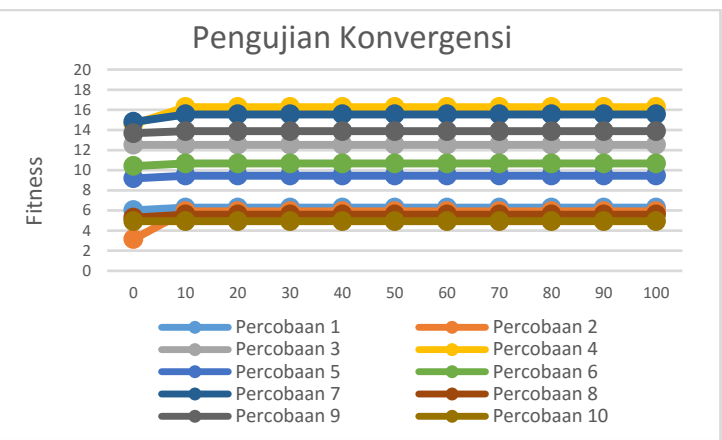

Gambar 4. Grafik Pengujian Konvergensi ELM-PSO

Dalam 10 kali percobaan terlihat bahwa sistem mulai menunjukkan konvergensi pada iterasi ke-10, namun masih belum mencapai kestabilan. Pada grafik terlihat bahwa sistem mencapai kestabilan iterasi pada iterasi ke-20.Nilai fitness yang didapatkan setelah iterasi ke-20 akan menghasilkan nilai fitness yang sama dengan iterasi sebelumnya. Pada grafik juga ditunjukkan nilai fitness terbesar yang dihasilkan oleh metode ELM-PSO yaitu pada Percobaan 4 dengan fitness terbesar 16.2712.

\section{PENUTUP}

\subsection{Kesimpulan}

1. Algoritma ELM-PSO dapat digunakan untuk mengoptimasi komposisi pakan kambing PE agar susu yang dihasilkan memiliki kandungan gizi susu yang maksimal, dimana cara kerjanya adalah dengan melakukan proses training data menggunakan algoritma ELM untuk memperoleh nilai input dan output weight yang nantiya akan digunakan pada algoritma PSO. Pada algoritma PSO akan dilakukan proses inisialisasi partikel dan partikel yang telah terbentuk akan diproses ke dalam ELM hingga diperoleh hasil denormalisasiya. Hasil denormalisasi tersebut akan digunakan untuk memperoleh nilai fitness yang dihasilkan oleh setiap partikel. Kemudian, sistem akan mencari nilai personal best (pBest) dan global best (gBest) serta dilakukan proses update kecepatan dan posisi hingga diperoleh satu partikel dengan nilai fitness terbesar.

2. Hasil pengujian yang dilakukan pada penelitian ini meliputi pengujian parameter optimal pada PSO serta pengujian konvergensi metode ELM-PSO. Parameterparameter optimal PSO adalah iterasi 
maksimal PSO $=100$ iterasi, nilai $w$ Max $=$ 0.6 dan $w$ Min $=0.3$, nilai $c_{1}=1$ dan $c_{2}=1.5$, nilai $k=0.6$. Parameter-parameter tersebut menghasilkan fitness terbaik sebesar 16.2712 dengan posisi partikel terbaik yaitu $\left[\begin{array}{llll}1.3659 & 1.1724 & 0.202 & 1.9077\end{array}\right]$. Pada pengujian konvergensi didapatkan bahwa sistem mencapai telah kestabilan nilai fitness, yaitu pada iterasi ke-20.

\subsection{Saran}

1. Diharapkan pada penelitian berikutnya dalam optimasi komposisi pakan kambing PE dapat ditambahkan atribut lain seperti harga pakan agar sistem dapat memberikan komposisi pakan terbaik dengan harga pakan yang diminimalkan.

2. Diharapkan pada penelitian berikutnya dalam menggunakan metode ELM-PSO juga dilakukan pengujian terhadap interval yang digunakan untuk mengetahui interval yang dapat menghasilkan solusi optimal.

\section{DAFTAR PUSTAKA}

AKUNTONO, I. (2015, September 29). Mengkhawatirkan, Angka Kelahiran di RI Tiap Tahun Setara Jumlah Penduduk Singapura. Retrieved Januari 8, 2016, from Kompas.com [online]:

http://nasional.kompas.com/read/2015/09/29/1 3574351/Mengkhawatirkan.Angka.Kelahiran.d i.RI.Tiap.Tahun.Sejumlah.Penduduk.Singapura

AMERILYSE, C., LATIFAH H. \& CHOLISSODIN I. 2016. Perbandingan Metode ANN-PSO dan ANN-GA dalam Pemodelan Komposisi Pakan Kambing Peranakan Etawa (PE) untuk Optimasi Kandungan Gizi (Studi Kasus pada UPT Pembibitan Ternak dan Hijauan Makanan Ternak Singosari-Malang). Jurnal Teknologi Informasi dan Ilmu Komputer (JTIIK) FILKOM UB Vol. 3 No. 3, 216-225.

ATMIYATI. 2001. Potensi Susu Kambing Sebagai Obat dan Sumber Protein Hewani Untuk Meningkatkan Gizi Petani. Bogor: Balai Penelitian Ternak.

CHOLISSODIN, I. 2016. Modul Analisis Big Data Semester Ganjil 2016-2017.

ENGELBRECHT, A. P. 2007. Computational Intelligence: An Introduction 2nd ed. West Sussex: John Wiley \& Sons Ltd.

FITRIYANTO, ASTUTI, T. Y., \& UTAMI, S. 2013. Kajian Viskositas dan Berat Jenis Susu Kambing Peranakan Etawa(PE) pada Awal, Puncak dan Akhir Laktasi. Jurnal Ilmiah Peternakan, 299-306.

HAMIDAH, E., SUKADA, I. M., \& SWACITA, I. B. 2012. Kualitas Susu Kambing Peranakan Etawah Post-Thawing pada Penyimpanan Suhu
Kamar. Indonesia Medicus Veterinus Edisi 3, 361-369.

HUANG, G. B., ZHU, Q. Y., \& SIEW, C. K. 2004. Extreme Learning Machine: A New Learning Scheme of Feedforward Neural Networks. Proceeding of International Joint Conference on Neural Networks. Hungary: Budapest.

HUANG, G. B., ZHU, Q. Y., \& SIEW, C. K. 2005. Extreme Learning Machine: Theory and applications. Elsevier science: Neurocomputing 70, 489-501.

NUGROHO, B. A. 2010. Pasar Susu Dunia dan Posisi Indonesia. JIIPB Vol. 20 No. 1, 65-76.

NUR, D. M., SETYOWATI, E., \& WAHYUNINGSIH, S. 2015. Performans Produksi Susu Kambing Peranakan Etawah(PE) Berdasarkan Paritas, Umur, Bobot Badan, dan Status Kebuntingan di "MADUKARA FARM", Kota Batu. Universitas Brawijaya, 1-7.

PRIHATMININGSIH, G. E., PURNOMOADI, A., \& HARJANTI, D. W. 2015. Hubungan antara Konsumsi Protein dengan Produksi, Protein dan Laktosa Susu Kambing Peranakan Ettawa. Jurnal Ilmu-ilmu Peternakan 25 Vol.2 , 20-27.

S, K. 2014. Classification of ECG Signals Using Hybrid Particle Swarm Optimization in Extreme Learning Machine. Journal of Applied Sciences and Engineering Research, Vol 3, No. 5, 1086-1095.

SUBEKTI, E. 2009. Ketahanan Pakan Ternak Indonesia. Mediagro, Vol.5, No.2 , 63-71.

SUN, Z., CHOI, T., AU, K., \& YU, Y. 2008. Sales Forecasting using Extreme Learning Machine with Application in Fashion Retailing. Elsevier Decision Support Systems 46, 411-419.

SUTAMA, I. K., \& BUDIARSANA, I. 1997. Kambing Peranakan Etawah Penghasil Susu sebagai Sumber Pertumbuhan Baru Sub-Sektor Peternakan di Indonesia. Balai Penelitian Ternak, 156-170.

UMIYASIH, U., \& ANGGRAENY, Y. N. 2007. Petunjuk Teknis Ransum Seimbang, Strategi Pakan pada Sapi Potong. Pasuruan: Pusat Penelitian dan Pengembangan Peternakan.

ZERDA, E. R. 2009. Analisis dan Penerapan Algoritma Particle Swarm Optimization (PSO) pada Optimasi Penjadwalan Sumber Daya Proyek. Bandung : Universitas Telkom.

ZURIATI, Y., MAHESWARI, R., \& SUSANTY, H. 2011. Karakteristik Kualitas Susu Segar dan Yoghurt dari Tiga Bangsa Kambing Perah dalam Mendukung Program Ketahanan dan Diversifikasi Pangan. Seminar Nasional Teknologi Peternakan dan Veteriner, 613-619. 